\title{
UN LIBRO, UNA PUERTA: \\ "DE LA DESAPARICIÓN A LA PERMANENCIA: INDÍGENAS E INDIOS EN LA REINVENCIÓN DEL CARIBE"
}

\section{Eliades Acosta Matos}

Director de Investigación del Archivo General de la Nación, República Dominicana.

Correo-e: eliadesignacio@yahoo.com

Cómo citar: Acosta Matos, E. (2018). Un libro, una puerta: "De la desaparición a la permanencia: indígenas e indios en la reinvención del Caribe”. Ciencia y Sociedad, 43(4), 87-88. doi: http://dx.doi.org/10.22206/cys.2018.v43i4.pp87-88

Con su compilación más reciente titulada De la desaparición a la permanencia: indigenas e indios en la reinvención del Caribe, los arqueólogos Roberto Valcárcel Rojas y Jorge Ulloa Hung, sus editores y compiladores, logran lo que raramente sucede con una obra colectiva: presentarnos las voces polifónicas de 16 autores como si se tratase de uno solo, sorteando los escollos de la multiplicidad de enfoques y tonos, incluso el riesgo omnipresente de incluir cuatro traducciones.

Se trata de un libro esperado. Desde hace algunas décadas vienen alzándose voces, como la de Ricardo Alegría, de Puerto Rico, José Barreiro, de Estados Unidos, y Alejandro Hartmann, de Cuba, en franca rebeldía contra la visión, a veces simplista y maniquea, de una tradición justiciera que, iniciándose con Bartolomé de las Casas y llegando hasta un segmento progre del campus y la academia estadounidense, principalmente de los 60 y 70, enarbolaron la visión de una absoluta y fulminante desaparición de los primeros habitantes de nuestra América, engullidos por la barbarie y las consecuencias de la conquista y la colonización europea.

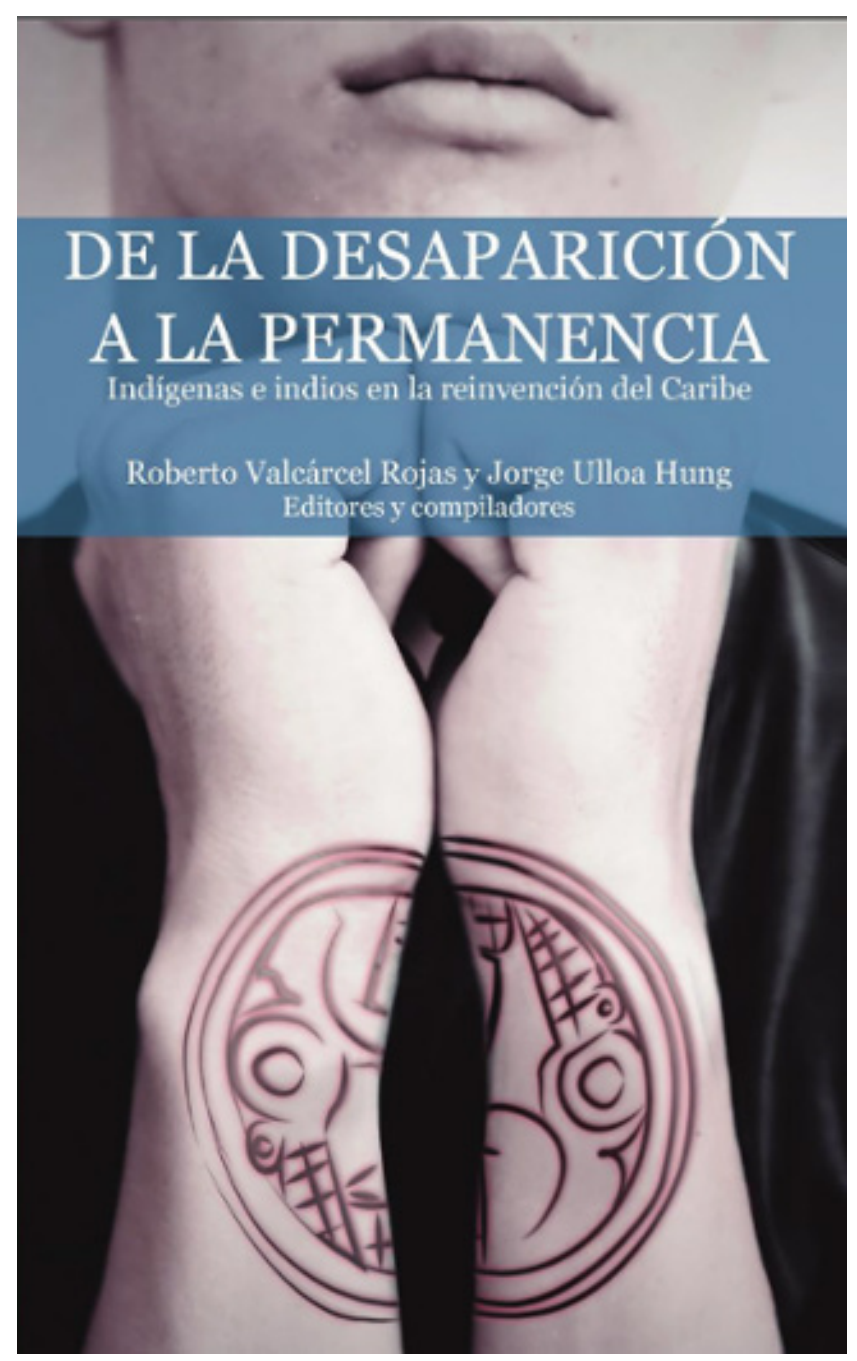


En rigor, la nueva visión de la cual esta compilación es deudora, no es exculpatoria, sino apegada a la realidad de los hechos y a las pruebas de las ciencias. Aún más: no redime de culpas históricas a los perpetradores del genocidio, sino que nos explica, con pruebas arqueológicas, históricas y documentales irrefutables, que por fuerza no pudo ser, y no fue, ni absoluto ni fulminante, y lo más importante: que la supervivencia de estos pueblos, en número e importancia mucho mayor de la que hasta el momento creíamos, no se debió a la benevolencia del invasor, sino a las estrategias de resistencia y supervivencias puestas en práctica por los invadidos usando para ello varias estrategias, entre ellas, el mestizaje.

Teníamos atisbos dispersos de lo que aquí se demuestra; de lo que los autores de la presente compilación nos explican mediante el despliegue de un corpus coherente. Sabíamos, por ejemplo, de la existencia de los caribes negros de San Vicente, descendientes de los náufragos de dos barcos con esclavos nigerianos naufragados cerca de esta isla en 1635, ancestros de los actuales garífunas de Honduras, Guatemala, Belice, Nicaragua y Estados Unidos, que hoy suman más de 600, 000 miembros, a pesar de la saña empleada contra ellos por los colonialistas británicos; o lo narrado en el extenso poema "La Florida", escrito en 1598 por Fray Alonso de Escobedo, franciscano andaluz que vivió diez años en Las Antillas, y nos describe, una década antes del célebre poema "Espejo de Paciencia", de Silvestre de Balboa, escribano canario del cabildo de Puerto Príncipe, la gran existencia de oro y de indios en Baracoa, Cuba, casi un siglo después de la llegada de Colón, cuando ambos se consideraban definitivamente agotados y exterminados.

Lo nuevo, conmovedor, y aportativo, en esta obra, es que se prueba la existencia de ese fenómeno en todo el Caribe, con diferentes características, pero obedeciendo a tendencias similares, desde la tenaz presencia de descendientes indios en Santiago de
Cuba, La Habana, Puerto Rico, San Vicente y las Granadinas coloniales, hasta la influencia del legado indígena en la cerámica y la artesanía de la República Dominicana. Y esta certeza no es producto de un espíritu redentor, ni de una aspiración a la justicia y condena del colonialismo y el imperialismo, sino de hechos científicos demostrables, fruto de la abnegada labor de arqueólogos, etnólogos e historiadores.

Se ha puesto de moda desmontar estatuas de Cristóbal Colón y otros prohombres europeos de la conquista y colonización europea de América, acusados de genocidio, como acaba de ocurrir en la ciudad de Los Ángeles, Estados Unidos, mientras se continúa reverenciando a los presidentes de ese mismo país, entre ellos a Ulysses Grant, que promovieron la sangrienta expansión hacia el oeste y el despojo de los pueblos aborígenes. Tales acciones suelen tener garantizada una amplia cobertura mediática y un acre debate posterior entre defensores y críticos. En rigor, y por lo general, no pasan de ser un espectáculo efímero y simplista que no contribuye a la restauración de la verdad histórica, a la condena de los verdaderos culpables y beneficiarios del genocidio, ni garantizan la dignidad ni los derechos de los descendientes de los afectados.

Con esta certera compilación de Rojas Valcárcel y Ulloa Hung, con los textos que ponen en nuestras manos los diversos autores, queda abierta una puerta a través de la que se puede vislumbrar un mundo ignoto y por reconstruir. Con la paciencia y entrega de arqueólogos e historiadores, se hace justicia perdurable y eficaz, lejos del bullicio y de las poses relumbronas.

Así actúa la ciencia verdadera. Y es de agradecer al Instituto Tecnológico de Santo Domingo y a la Fundación García Arévalo, el haber puesto esta obra oportuna en manos de los lectores de nuestro tiempo. 